\title{
USE OF RENEWABLE ENERGY SOURCES AS A TOOL SUPPORTING THE PROTECTION OF CULTURAL VALUES OF WARSAW'S SUBURBS: CASE STUDY OF MANOR IN WARSAW-BIAŁOŁĘKA
}

\author{
Justyna Zdunek-Wielgołaska ${ }^{\bowtie}$, Klara Kantorowicz, Krzysztof Rudzki \\ Faculty of Architecture, Warsaw University of Technology
}

\begin{abstract}
The article aims to present the research results on the possibility of using alternative energy sources and pro-ecological solutions as a tool supporting the protection of the cultural and natural landscape of the suburbs of Warsaw. Near Warsaw, there are individual objects or complexes that constitute this area's cultural identity. The difficulty is to adapt them to current energy standards without interfering with their original material, especially concerning wooden buildings. Instead of subjecting them to thermal modernization, it is worth considering alternative solutions, such as photovoltaics. A wooden manor house in Warsaw-Białołęka was selected for detailed research. The study has shown that the optimal use of 26 photovoltaic modules that were adopted with a total installation capacity of $7.54 \mathrm{~kW}_{\mathrm{p}}$ will be optimal for this type of edifice. The simple payback time of the investment will be about ten years. To eliminate the negative aesthetic effect of the installation, panels in the appropriate color should be used, or the use of photovoltaic tiles should be considered, although the investment costs will increase. The study has shown indisputable benefits, including economic ones, resulting from the solutions used.
\end{abstract}

Key words: heritage protection, renewable energy, photovoltaic installation, manor in Białołęka, Warsaw's suburbs

\section{INTRODUCTION}

Although there are legal regulations to protect valuable landscape elements, at least in principle, they do not always work in practice, especially in the face of enormous investor pressure in the suburbs of large cities. What is more, these regulations do not consider the possibilities arising from modern technologies used to obtain energy from alternative sources that, if implemented with care and preparation, could qualitatively improve the quality of life in the suburbs and help protect the landscape.
The high development dynamics of the alternative energy market results primarily from the growing awareness of responsibility for the environment in which we live (López \& Frontini, 2014). New technologies and materials allow increasing the energy efficiency of buildings, which brings both environmental and economic benefits by reducing expenses for their maintenance and use.

Maintaining facilities with historical value is associated with large financial expenditures related to their use. For residential buildings, the owners' budget is mainly involved, guided by the economic calculation. 
Zdunek-Wielgołaska, J., Kantorowicz, K., Rudzki, K. (2021). Use of renewable energy sources as a tool supporting the protection of cultural values of Warsaw's suburbs: case study of manor in Warsaw-Białołęka. Acta Sci. Pol. Architectura, 20 (1), 13-23. doi: 10.22630/ASPA.2021.20.1.2

Quite often, owners want to reduce the costs of maintenance and decide to introduce thermo-modernisation, which, if implemented improperly, blurs the historical value of a building. Therefore, this research aimed to check if using alternative energy sources in these unique facilities would be a more appropriate solution, for example, due to the preservation of material and structural authenticity. Making energy demand statements for a representative facility allowed estimating the energy balance for a larger group of facilities of this type.

\section{MATERIAL AND METHODS}

\section{General assumptions}

When choosing a building, attention was paid to the monuments of residential architecture placed in the landscape, which characterise the suburbs' dominant function the most, i.e. residential function. It was crucial to find buildings related to the landscape surrounded by composed greenery, often also under conservation protection. The research took into account the suburban area of Warsaw, which was defined based on the distance from the centre. It covered the peripheral districts of the city itself and all communes neighbouring Warsaw. For each of the selected communes and districts, a quantitative summary of historical buildings listed on the register of monuments was made, broken down into buildings' original functions. On this basis, the main functional groups of historical buildings were identified. Among the selected types, representative examples have been identified closely related to the history of a given district or town. When choosing, special attention was paid to buildings listed on the register as elements of historical complexes, or together with the surrounding historical greenery surrounding them (Fig. 1).

One representative example was selected from the Warsaw suburb area to be examined in detail in terms of its energy balance.

Suburban zones, currently closely integrated into the entire Warsaw agglomeration, have developed based on very diverse villages and towns. Their current structure is mainly due to historical development, former land parcelling, or the period in which changes in a given area's functioning were marked (Solarek,
2014). Historical buildings are closely related to the history of the place. Their type, density, or location in the field testify to the historical development of a given town and its former shape. Not only are they silent witnesses to the history of a given place, they still create a unique character of the landscape of a town or a district. Monuments are mostly responsible for a place's specific atmosphere, protecting it against Warsaw's suburban areas' unification and homogenisation.

As part of spatial analyses of the distribution of monuments listed on the register of monuments in the suburbs of Warsaw, the following communes neighbouring Warsaw were taken into account: Konstancin-Jeziorna (urban and rural commune), Piaseczno (urban and rural commune), Lesznowola, Raszyn, Michałowice, Piastów, Pruszków, Ożarów Mazowiecki (urban and rural commune), Stare Babice, Izabelin, Łomianki (urban and rural commune), Jabłonna, Legionowo, Nieporęt, Marki, Kobyłka, Wołomin (urban and rural commune), Ząbki, Zielonka, Sulejówek, Halinów (urban and rural commune), Wiązowna, Józefów, Otwock and Karczew, and its peripheral districts: Wilanów, Ursynów, Włochy, Ursus, Bemowo, Bielany, Białołęka, Rembertów, Wesoła and Wawer. As can be seen on the map showing the number of monuments in individual communes and districts, these areas are very diverse in terms of the functional structure of monuments. Places with a history related to the development of industry such as Konstancin-Jeziorna, Piaseczno, or Pruszków are clearly visible, as well as towns created in empty agricultural areas, where very few objects of historical value have been preserved. Attention should be paid to places where there are many historic residential buildings: villas and single-family houses. Primarily, these are areas of summer villages near Warsaw: Konstancin and Otwock, along with areas along the so-called Otwock line (currently Wawer district and Józefów commune). Similar conditions also apply to former summer villages located a little further from the borders of Warsaw: Podkowa Leśna or Milanówek. The type and number of monuments in individual communes are therefore closely related to their history and results from the use of land, as well as the structure of the communication network. 
Zdunek-Wielgołaska, J., Kantorowicz, K., Rudzki, K. (2021). Use of renewable energy sources as a tool supporting the protection of cultural values of Warsaw's suburbs: case study of manor in Warsaw-Białołęka. Acta Sci. Pol. Architectura, 20 (1), 13-23. doi: 10.22630/ASPA.2021.20.1.2

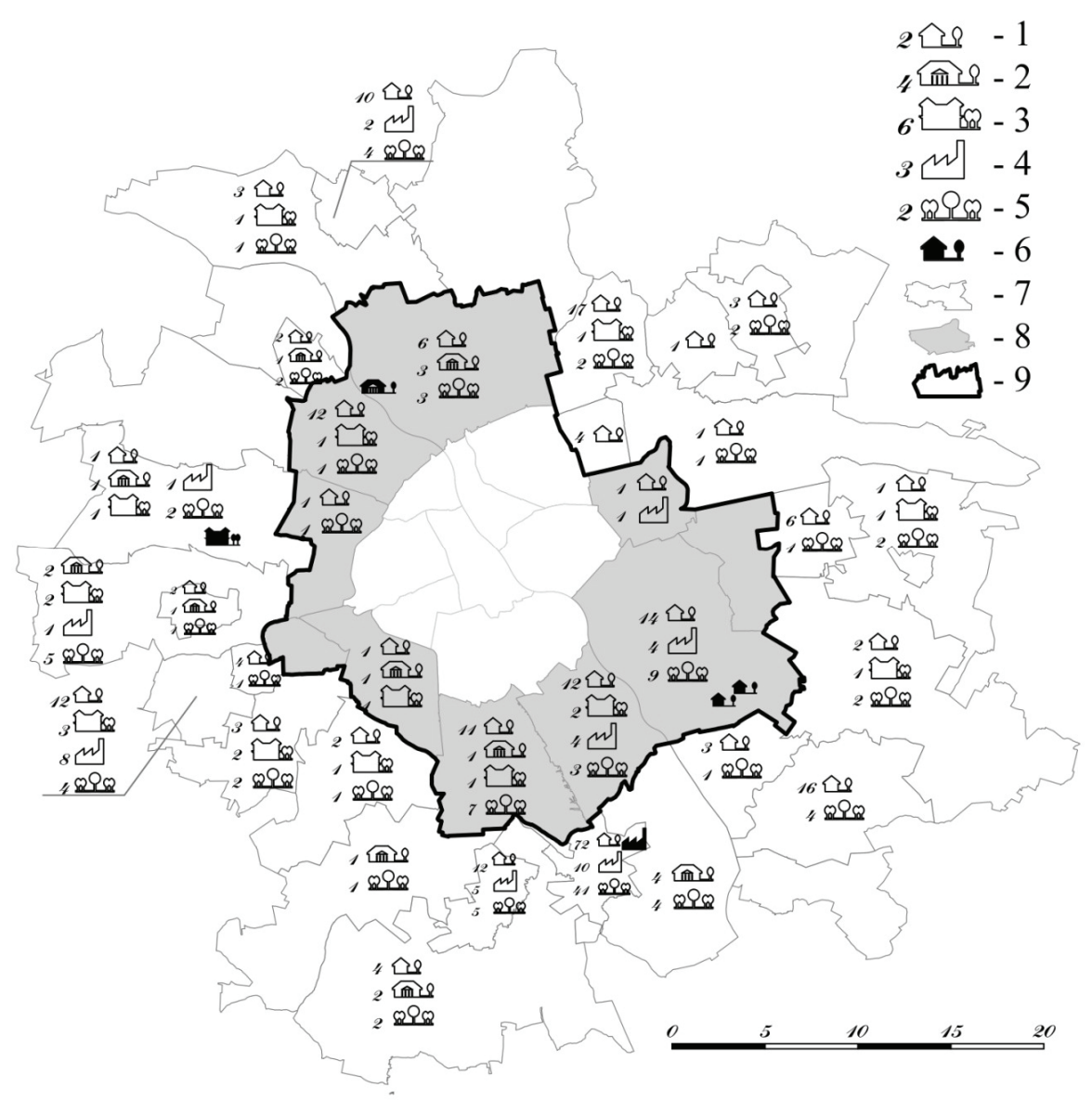

Legend: 1 - number of historic residential buildings in the commune, 2 - number of historical manors in the commune, 3 - number of historical palaces in the commune, 4 - number of historical industrial buildings in the commune, 5 - number of historical greenery in the commune, 6 - location of the buildings selected for analysis, 7 - borders of communes neighbouring Warsaw, 8 - suburbs of Warsaw, 9 - borders of Warsaw

Fig. 1. Summary of the number of monuments in the suburbs of Warsaw with the location of the buildings selected for analysis (created by K. Kantorowicz in 2018 based on data from the National Heritage Board of Poland geoportal https://mapy.zabytek.gov.pl)

When choosing the buildings, attention was paid to monuments of residential architecture placed in the landscape and industrial architecture complexes. It was essential to find buildings related to the landscape surrounded by composed greenery, often also under conservation protection. Five types of edifices meet the above assumptions. Those were residential villas surrounded by gardens, mansions, and palaces located in parks, often accompanied by outbuildings and post-industrial buildings forming or being part of larger complexes.
Sacred buildings were excluded from the analyses, and although they constitute a significant part of the historical resource of the areas in question, they have a cubature that is disproportionate to their usable area, resulting mainly from their function. Tenement buildings forming compact urban structures were also excluded, as they constitute a relatively uniform tissue of intensively built-up regions and do not have spatial and functional connections with the open landscape of the suburbs.

Historical public buildings such as town halls, taverns, and railway stations were also not included 
Zdunek-Wielgołaska, J., Kantorowicz, K., Rudzki, K. (2021). Use of renewable energy sources as a tool supporting the protection of cultural values of Warsaw's suburbs: case study of manor in Warsaw-Białołęka. Acta Sci. Pol. Architectura, 20 (1), 13-23. doi: 10.22630/ASPA.2021.20.1.2

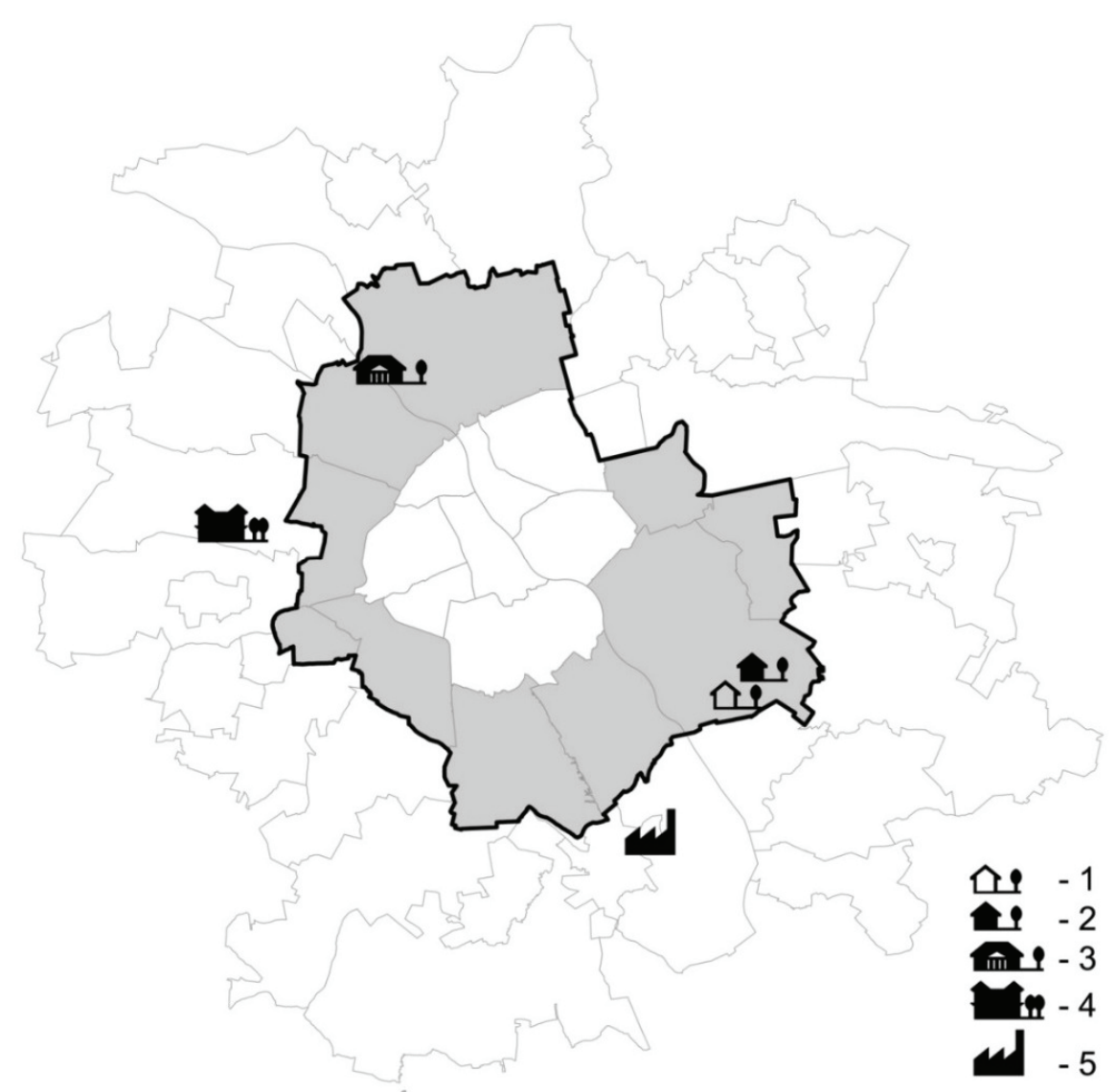

Legend: 1 - wooden villa in Warsaw-Falenica in the Świdermajer style, 2 - stone villa in Warsaw-Falenica, 3 - wooden manor in Warsaw-Białołęka, 4 - brick Lasotow Palace in Zielonki-Parcela, 5 - brick post-industrial building in the lower paper mill complex in Konstancin-Jeziorna

Fig. 2. Warsaw suburbs with buildings selected for analysis (created by K. Kantorowicz in 2018 based on data from the National Heritage Board of Poland geoportal https://mapy.zabytek.gov.pl)

due to their small numbers in the area in question and a large variety of forms and sizes of buildings, which would make it challenging to select representative examples from among them.

From among the buildings diversified in terms of cubature, materials, and construction, as well as the original function, five groups of them were finally distinguished: brick villas, wooden villas, manors, palaces, and brick industrial buildings, and one representative example was chosen from each (Fig. 2).

In the current study, wooden manor in Warsaw-Białołęka district was chosen for detailed analysis of energy demand and potential use of renewable resources for electricity production.

\section{Wooden manor in Warsaw-Białołęka}

\section{Administrative data}

A wooden manor house located in the historical park stretching on the Vistula right bank within the boundaries of the Białołęka district at 2 Mehoffer Street is listed on the register of monuments by the decision of 1 July 1973 under symbol 644/3. The manor building is located on the south-western edge of the park (also listed in the register of monuments by the decision of 1 July 1973 marked as 644/1-2), near the Vistula. The manor building is located on the border of two plots (42 and 2/10) belonging to the Higher Seminary of Our Lady Victorious Diocese of Warsaw-Praga. The 
Zdunek-Wielgołaska, J., Kantorowicz, K., Rudzki, K. (2021). Use of renewable energy sources as a tool supporting the protection of cultural values of Warsaw's suburbs: case study of manor in Warsaw-Białołęka. Acta Sci. Pol. Architectura, 20 (1), 13-23. doi: 10.22630/ASPA.2021.20.1.2

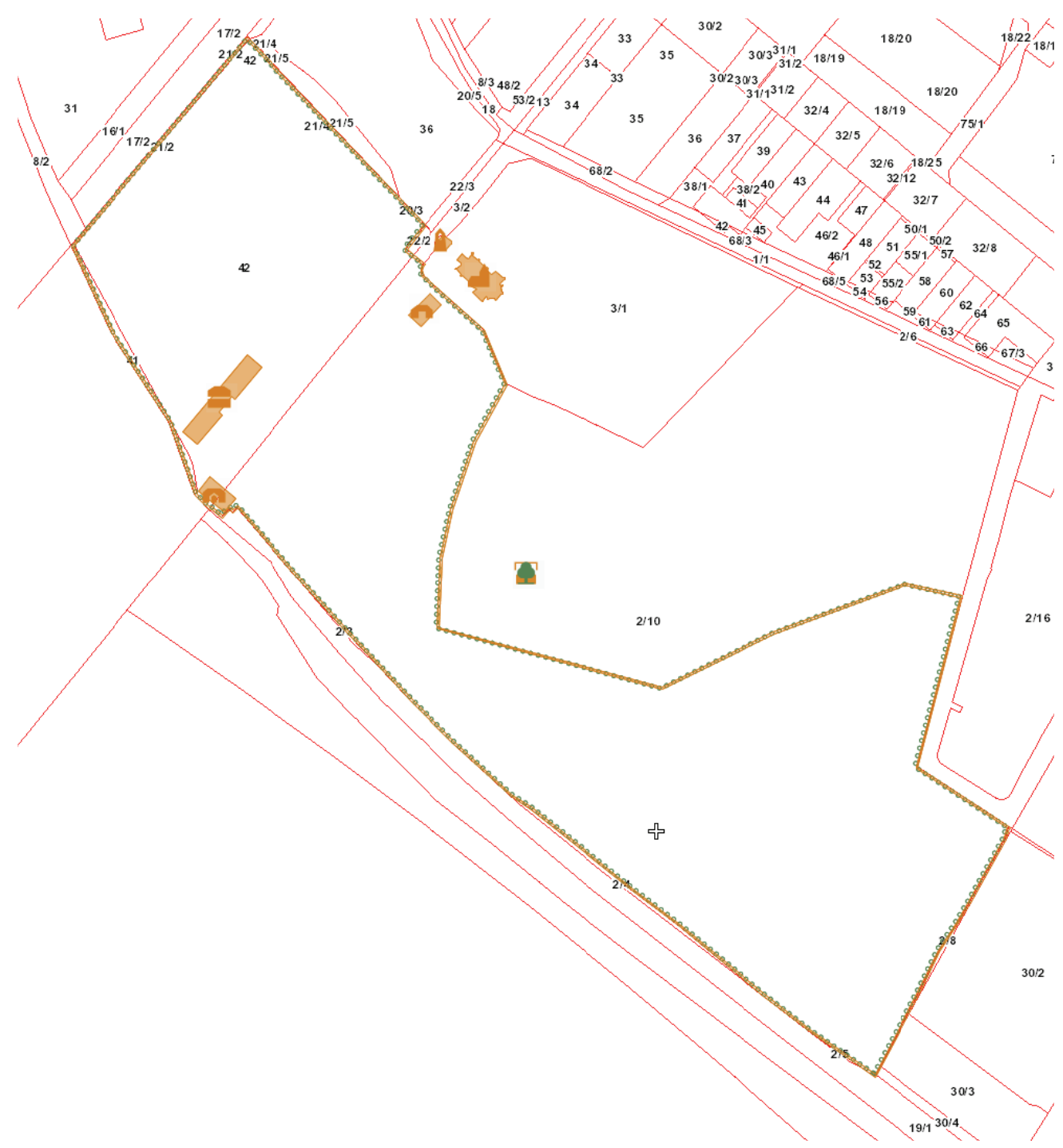

Fig. 3. Location of historical buildings of the Mostowski manor complex and range of the historical park (created by K. Kantorowicz in 2018 based on data from the National Heritage Board of Poland geoportal https://mapy.zabytek. gov.pl)

historical park, on which the building is located, covers the entire plot 42 and the south-western part of the plot 2/10 (Fig. 3).

\section{History of the building}

The manor house dates back to the mid-18th century. It was built for Józef Jan Kante Ossoliński, who was the collector of the Tarchomin temple. Formerly, it was located on the natural Vistula embankment, but now it is obscured by an earthen embankment.
The historical complex is known as the Mostowski manor complex, and it changed considerably after 1790 when Tarchomin passed into Tadeusz Mostowski. He decided to transform the establishment into a palace complex and commissioned the new residence's design to Szymon Bogumił Zug. The project was not implemented, and only the outbuilding was built in 1801-1825, most likely according to the design of Henryk Ittar. The massive body of the two-story outbuilding covered with a hipped roof 
Zdunek-Wielgołaska, J., Kantorowicz, K., Rudzki, K. (2021). Use of renewable energy sources as a tool supporting the protection of cultural values of Warsaw's suburbs: case study of manor in Warsaw-Białołęka. Acta Sci. Pol. Architectura, 20 (1), 13-23. doi: 10.22630/ASPA.2021.20.1.2

with dormers overwhelmed the main element of the former manor house, destroying the original composition assumptions (Pilch, 1999).

\section{History of the region context}

The wooden manor is closely connected with the oldest history of Tarchomin, which was a noble village located on the Vistula route from Warsaw to Jabłonna. Along with the nearby late Gothic church, it formed an important compositional axis of the former Tarchomin. The symmetrical composition of the building's body is related to the park's composition surrounding the manor. The main access avenue, an extension of Mehoffer Street (the former road leading to the Warsaw route and further to Modlin), is directed towards the manor's axially located entrance. The building closes the composition of an oval lawn closing the access avenue.

Tarchomin estate has changed owners many times. The park complex was formed during the reign of the mentioned Jan Kante Ossoliński, who took over Tarchomin in 1738 and built the manor house and initiated the current park establishment (Fig. 4).

Białołęka, being a district of Warsaw that was urbanised relatively late, has few historical buildings. Within its boundaries, there are as many as three manors that are a testimony to the history of these areas as landed goods. The manor located in the com- plex at Mehoffer Street is the oldest, and therefore the most valuable of the historical manors of Białołęka. Other noble seats (located at Stasinek Street and Dębowa Street on the northern edge of the district) are stone mansions from the first half of the 19th century.

\section{Building description - shape and material}

The building has a compact shape and represents a typical baroque manor. Established on a rectangular plan (Fig. 5) and covered with a hipped roof, the Polish manor house is preceded by a portico supported on four slender columns. The one-storey building is founded on a brick basement full of vaults. The walls of the manor are made of wooden beams in a log construction covered on both sides with lime-gypsum plaster. The roof has a queen post design and slopes inclined at an angle of $45^{\circ}$, covered with shingles. The ceiling above the ground floor made of wooden beams is lined with a soffit ceiling and plastered. Wooden doors are made of boards; they are feathered with profiled staves, while the windows are traditional wooden, three-part.

The building is positioned along the NW-SE axis with the facade is facing north-east. Most of the window openings (six out of nine) are placed on the front facade, which means that the interiors are dark and underexposed. The rear wall facing the south-west has no window openings.

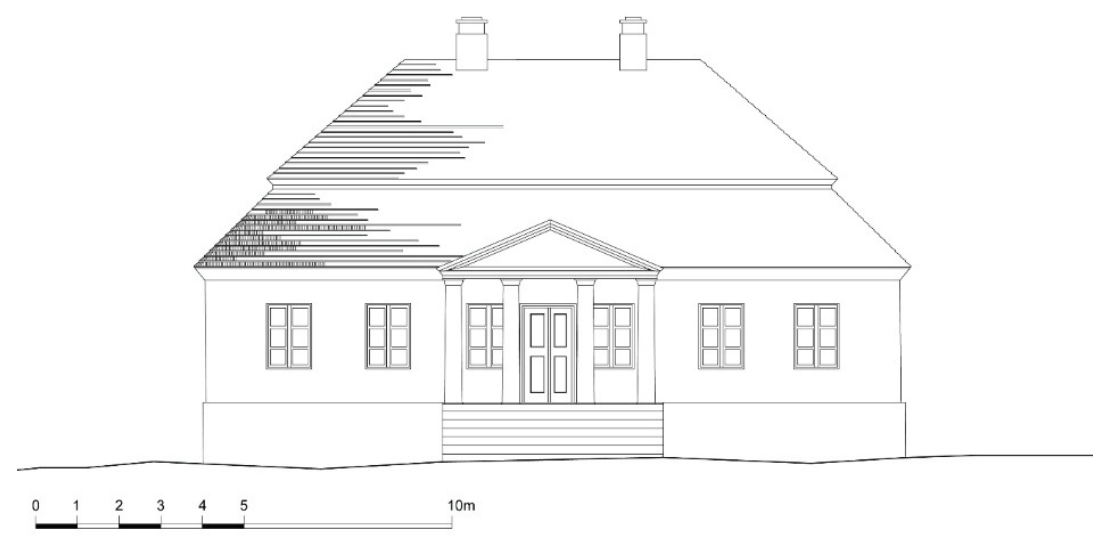

Fig. 4. Front facade of the historical manor at Mehoffer Street (redrawn by K. Kantorowicz in 2018 based on so-called white card of the monument published in Pilch, 1999) 
Zdunek-Wielgołaska, J., Kantorowicz, K., Rudzki, K. (2021). Use of renewable energy sources as a tool supporting the protection of cultural values of Warsaw's suburbs: case study of manor in Warsaw-Białołęka. Acta Sci. Pol. Architectura, 20 (1), 13-23. doi: 10.22630/ASPA.2021.20.1.2

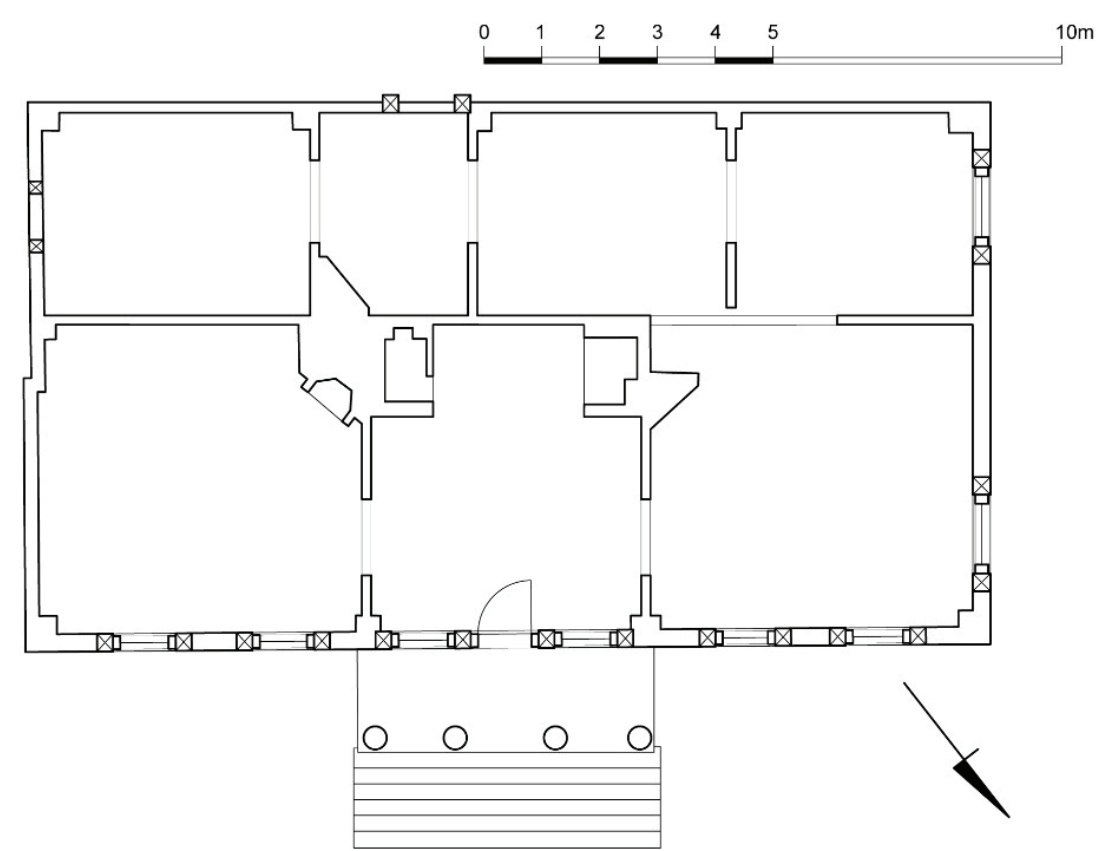

Fig. 5. Plan of the ground floor of the historical manor at Mehoffer Street (redrawn by K. Kantorowicz in 2018 based on so-called white card of the monument published in Pilch, 1999)

\section{Calculations}

\section{Energy demand}

The building's energy demand was calculated under the 2015 Regulation of the Minister of Infrastructure and Development on building energy performance methodology and certification (Rozporządzenie Ministra Infrastruktury i Rozwoju w sprawie metodologii wyznaczania charakterystyki energetycznej budynku lub części budynku oraz świadectw charakterystyki energetycznej, Dz.U. 2015 poz. 376). The data for calculating the building's energy demand was taken from the available building documentation, building inventory, and construction outcrops.

\section{Building parameters adopted for calculations}

In the analysed buildings, the energy carrier in the heating and ventilation system, as well as the hot water system, is electricity. Heat for the heating system and the hot water system for utility purposes is generated by means of a dual-function compressor air pump/electrically driven air. The heating system uses central and local regulation radiators with a thermostatic valve with PI (proportional-integral controller) proportional integration action with adaptive and optimisation functions. The heating system uses a heat source located in a heated room with insulated wires, fittings, and devices installed in the heated space and a domestic hot water boiler. The heating system uses an auxiliary device that consumes electricity - a water circulation pump. The hot water system for utility purposes uses an auxiliary device consuming electricity - a water circulation pump. The analysed building has gravitational ventilation.

Potential to use electricity produced by photovoltaic system installations

When calculating the value of electrical energy production from a given photovoltaic (PV) panel, the inclination of the PV panel relative to the horizontal plane and the orientation towards the south should be taken into account. The PV modules' efficiency, which depends on the type of cells used in the PV module, and the location that affects the annual sum of solar 
Zdunek-Wielgołaska, J., Kantorowicz, K., Rudzki, K. (2021). Use of renewable energy sources as a tool supporting the protection of cultural values of Warsaw's suburbs: case study of manor in Warsaw-Białołęka. Acta Sci. Pol. Architectura, 20 (1), 13-23. doi: 10.22630/ASPA.2021.20.1.2

radiation incidents on a given surface, should be considered. An essential element affecting electricity production is the loss of the entire PV system installed on the building, and a decrease in the modules' efficiency depending on the module's operating temperature. The amount of electric energy produced by the PV panel in winter is much lower than in summer, which significantly affects the percentage of the current use of electricity from PV installations.

In the current work, five variants of calculations were considered: $\mathrm{W} 0$ - base variant, $\mathrm{W} 1 \mathrm{a}$ and $\mathrm{W} 1 \mathrm{~b}-$ installation of $26 \mathrm{PV}$ modules, W2a and W2b. Variants W1a and W2a assumed that the excess of electricity produced by PV panels in excess of the building's current demand is lost. Variants W1b and W2b assumed that the excess electricity produced by PV panels, in excess of the buildings current demand, is stored in the power grid.

\section{RESULTS AND DISCUSSION}

\section{Economic result}

In variants $\mathrm{W} 1 \mathrm{a}$ and $\mathrm{W} 1 \mathrm{~b}, 26$ photovoltaic modules were adopted with a total installation capacity of $7.54 \mathrm{~kW}_{\mathrm{p}}$ (Table 1). The model assumes placing the modules on the building's roof at an angle of $45^{\circ}$ degrees to the horizontal plane and in the south-west horizontal orientation. The total cost of the photovoltaic installation in variants $\mathrm{W} 1 \mathrm{a}$ and $\mathrm{W} 1 \mathrm{~b}$ would be PLN 33,176 and would reduce electricity costs by PLN 3,290 per year, which would give a return on investment expenditure in 10.1 years (Table 1).

In the W2a and W2b variants (Table 2), the number of PV modules taken for calculations was selected so that the power did not exceed $10 \mathrm{~kW}_{\mathrm{p}}$. It would be possible to place 26 south-west oriented PV modules with $7.54 \mathrm{~kW}_{\mathrm{p}}$ capacity and eight south-east oriented

Table 1. Economic parameters of the analysed variants

\begin{tabular}{lccc}
\hline Specification & \multicolumn{3}{c}{ Variants considered } \\
\cline { 2 - 4 } & W0 & W1a, W1b & W2a, W2b \\
\hline Total power of PV panels $\left[\mathrm{kW}_{\mathrm{p}}\right]$ & - & 7.54 & 9.86 \\
\hline Annual energy production by PV system $[\mathrm{kWh}]$ & - & 7042 & 9290 \\
\hline Annual cost of using the building [PLN] & 8384 & 5094 & 4152 \\
\hline Investment costs [PLN] & - & 33176 & 43384 \\
\hline Simple payback time $[$ year] & - & 10.1 & 10.3 \\
\hline
\end{tabular}

Table 2. The energy demand of analysed variants

\begin{tabular}{lccccc}
\hline \multirow{2}{*}{ Specification } & \multicolumn{5}{c}{ Variants considered } \\
\cline { 2 - 6 } & W0 & W1a & W2a & W1b & W2b \\
\hline Annual energy production by PV $[\mathrm{kWh}]$ & - & 7042 & 9290 & 7042 & 9290 \\
\hline $\begin{array}{l}\text { Annual energy production by PV included in the calculation } \\
\text { for end energy demand indicator }(\mathrm{EK})[\mathrm{kWh}]\end{array}$ & - & 3404 & 3452 & 6315 & 8123 \\
\hline Annual final energy index $\left[\mathrm{kWh} \cdot \mathrm{m}^{-2}\right]$ & 65 & 51 & 50 & 38 & 31 \\
\hline Annual initial energy index $\left[\mathrm{kWh} \cdot \mathrm{m}^{-2}\right]$ & 195 & 152 & 151 & 115 & 93 \\
\hline
\end{tabular}

\footnotetext{
${ }^{1}$ Abbreviation used further in this article for technical requirements is WT (from Polish warunki techniczne).
} 
Zdunek-Wielgołaska, J., Kantorowicz, K., Rudzki, K. (2021). Use of renewable energy sources as a tool supporting the protection of cultural values of Warsaw's suburbs: case study of manor in Warsaw-Białołęka. Acta Sci. Pol. Architectura, 20 (1), 13-23. doi: 10.22630/ASPA.2021.20.1.2

PV modules with $2.32 \mathrm{~kW}_{\mathrm{p}}$ capacity, and the total installation power is $9.86 \mathrm{~kW}_{\mathrm{p}}$. The modules would also be placed on the building's roof at an angle of $45^{\circ}$ to the horizontal plane. The total cost of the PV installation in variants W2a and W2b in the year 2018 would be PLN 43,384 and would reduce electricity costs by PLN 4,232 per year and give a return on investment expenditure in 10.3 years (Table 1 ).

In the base variant $\mathrm{W} 0$, the building has a primary energy demand index of $195 \mathrm{kWh} \cdot \mathrm{m}^{-2} \cdot \mathrm{year}^{-1}$ (Table 2), which exceeds the Polish requirements according to 2017 amendment of the Regulation of Minister of Infrastructure and Construction on technical requirements ${ }^{1}$ for buildings and their location (Rozporządzenie Ministra Infrastruktury i Budownictwa zmieniające rozporządzenie w sprawie warunków technicznych, jakim powinny odpowiadać budynki oraz ich usytuowanie, Dz.U. 2017 poz. 2285). Variant W1a uses a PV installation on the roof of the building from the south-west with a capacity of $7.54 \mathrm{~kW}_{\mathrm{p}}$ (Table 1). The calculations did not take into account the electric energy storage in the power grid, due to which the primary energy demand index only decreased to $152 \mathrm{kWh} \cdot \mathrm{m}^{-2} \cdot \mathrm{year}^{-1}$ (Table 2), which still exceeds the WT 2017 requirement. For the W1b variant that considers the possibility of partial storage of electric energy in the power grid, the primary energy demand index will decrease to $115 \mathrm{kWh} \cdot \mathrm{m}^{-2} \cdot$ year $^{-1}$ (Table 2), which does not meet the requirements of the WT 2017. For the W2a variant that consists in covering the roof of the building with PV modules so that their power does not exceed $10 \mathrm{~kW}_{\mathrm{p}}$ on both roof slopes, and assuming the possibility of partial storage of electric energy in the power grid, the primary energy demand index will decrease to $93 \mathrm{kWh} \cdot \mathrm{m}^{-2} \cdot$ year $^{-1}$ (Table 2) that meets the WT 2017 requirement but does not meet the WT 2021 requirement. For the W2b variant, the final energy demand index will decrease to $31 \mathrm{kWh} \cdot \mathrm{m}^{-2}$. -year ${ }^{-1}$ (Table 2), which, however, is not enough for the building to be treated as a passive building.

In the W2a variant, it was assumed that the excess electricity produced by PV panels, in excess of the building's current demand, is lost. In the W2b variant, it was assumed that the excess electricity produced by PV panels, in excess of the building's current demand, is stored in the power grid.
Comparing the simple payback time of the investment, consisting of installing PV modules on the roof of a historic building, we get a value of about 10 years (Table 1).

Photovoltaic panels installed on the roof of the facility do not have any moving parts and are made of materials subject to corrosion to a minimal extent, which means that the duration of failure-free operation of PV panels can be assumed at least for 20 years. Looking generally at the entire PV system, the least durable element is an inverter (inverter) that changes the direct current supplied by the PV panel into alternating current, the durability of this element can be assumed for about 10 years. The share of the inverter cost in the total system cost for a small roof installation is about $20 \%$ of the total. Comparing the time of return on investment of around 10 years to the lifetime of PV cells of around 20 years, it can be concluded that it is a sufficient time for the return on investment, which provides the investor with the profitability of the asset against the background of using only electricity supplied from the grid.

\section{Optimal orientation}

Calculations were conducted for PV panels are installed on the south-western slope (variants W1a and W1b) and on the south-western and the south-eastern slope (variants W2a and W2b).

The account of the roof slope in the analysed building is $45^{\circ}$. In Poland's climatic conditions, the optimal orientation of PV panels is the south at an angle of about $35^{\circ}$. In the analysed building, the opposite slopes have similar surfaces suitable for the installation of PV panels; hence it follows that changing the orientation of the building by $180^{\circ}$ will result in installing the panels on opposite roof slopes, but the electric energy yield will not change. Currently, due to the amount of electricity produced from $\mathrm{PV}$, the building is in an indirect orientation. Placing the building in the most unfavourable orientation, i.e. with an east or west orientation of the roof slope with a larger area, will reduce electricity production by $12.3 \%$ for the east orientation and $14.5 \%$ for the west orientation. Setting the building in the optimal orientation, i.e. the south, will increase electricity production by $5.3 \%$ compared to the current output. This discussion 
Zdunek-Wielgołaska, J., Kantorowicz, K., Rudzki, K. (2021). Use of renewable energy sources as a tool supporting the protection of cultural values of Warsaw's suburbs: case study of manor in Warsaw-Białołęka. Acta Sci. Pol. Architectura, 20 (1), 13-23. doi: 10.22630/ASPA.2021.20.1.2

shows that PV panels' orientation is an essential factor affecting the energy yield and the associated payback time. A separate calculation should be made for each building, taking into account the roof's slope and the building's orientation.

\section{Aesthetic effect}

On the south-western roof slope, the maximum number of PV panels was placed, which, taking into account the design standards, would fit on the roof slope, i.e. $42.7 \mathrm{~m}^{2}$. On the south-eastern roof slope, PV panels with an area of $13.1 \mathrm{~m}^{2}$ were placed. It should be assumed that the panels will be visible on the roof of the building, but the products already available on the market can minimise this effect (currently on the market, there are photovoltaic panels in various colours and forms, e.g. as PV tiles).

\section{CONCLUSIONS}

The research has shown that alternative energy sources would help its users reduce the costs of maintaining such buildings and protect against interference associated with thermo-modernisation that often destroys historical value. Often, buildings with historical value deteriorate because owners do not have the resources to maintain them properly. Therefore, it seems that help should be organised at the level of the commune. This could occur based on a subsidy loan for renewable energy sources and building modernisation. If, as a result of energy analyses, it would turn out that a larger area of PV panels is needed, and the outstanding historical value of a given building or its technical constraints would not allow to install them, then the owner of such a historical building could be allowed to install PVs on another plot belonging to the commune, intended for this purpose. The commune could provide a large undeveloped plot to the owners of all historical buildings in the commune. This can be justified, since from the point of view of the emission itself, it does not matter whether energy is produced within the building or on the plot, e.g. a few kilometres away, it will be consumed by the neighbours of these plots in a given commune. Such a solution would be worth studying and considering as a systemic solution in the future.
Monuments that in the suburbs take the form of larger complexes in greenery or as individual structures are read in the wider context of closer and further surroundings, thus having a qualitative impact on reception on a larger urban scale, are great cultural carrier values. The use of alternative energy sources and pro-ecological solutions can become a useful tool conducive to protecting the cultural and natural landscape of the suburbs of Warsaw. When introducing this type of solution, it is important to interfere with the valuable tissue and the aesthetic appearance with particular caution, so solutions from which the interference in the monument should be as minimal as possible.

The conducted tests prove the legitimacy of using alternative energy sources and pro-ecological solutions in buildings of historical value. Detailed calculations have also shown that taking into account the effect of electric energy storage in the grid when calculating the building's energy demand results in a significant reduction of final energy (EK) and primary energy (EP) indices and allows meeting the requirements resulting from the provisions of the WT 2002 (Rozporządzenie Ministra Infrastruktury w sprawie warunków technicznych, jakim powinny odpowiadać budynki oraz ich usytuowanie, Dz.U. 2002 nr 75 poz. 690), as well as allows meeting energy standards, which are to be binding in 2021. Alternative energy sources could become a good choice that would complement thermomodernisation, or even replace it, which will undoubtedly protect the historical value of many buildings.

\section{Authors' contributions}

Conceptualization: J.Z.-W.; methodology: J.Z.-W. and K.R.; formal analysis: K.R.; investigation: K.K. and K.R.; resources: K.K.; data curation: K.R.; writing - original draft preparation: J.Z.-W., K.K. and K.R.; writing - review and editing: J.Z.-W.; visualisation: K.K.; supervision: J.Z.-W.; project administration: J.Z.-W.

All authors have read and agreed to the published version of the manuscript.

\section{Acknowledgements}

This work was supported by the Faculty of Architecture, Warsaw University of Technology (grants: 504/03619/1010/40.000100 and 504/04541/1010/43. 010017). 
Zdunek-Wielgołaska, J., Kantorowicz, K., Rudzki, K. (2021). Use of renewable energy sources as a tool supporting the protection of cultural values of Warsaw's suburbs: case study of manor in Warsaw-Białołęka. Acta Sci. Pol. Architectura, 20 (1), 13-23. doi: 10.22630/ASPA.2021.20.1.2

\section{REFERENCES}

López, C. S. P. \& Frontini, F. (2014). Energy Efficiency and Renewable Solar Energy Integration in Heritage Historic Buildings. Energy Procedia, 48, 1493-1502. https:// www.doi.org/10.1016/J.EGYPRO.2014.02.169

Pilch, J. (1999). Karta Biała Zabytku: Założenie pałacowo-ogrodowe, Dwór, Warszawa, ul. Mehoffera 2. Narodowy Instytut Dziedzictwa.

Rozporządzenie Ministra Infrastruktury i Budownictwa z dnia 14 listopada 2017 r. zmieniające rozporządzenie w sprawie warunków technicznych, jakim powinny odpowiadać budynki oraz ich usytuowanie (Dz.U. 2017 poz. 2285).
Rozporządzenie Ministra Infrastruktury i Rozwoju z dnia 27 lutego 2015 r. w sprawie metodologii wyznaczania charakterystyki energetycznej budynku lub części budynku oraz świadectw charakterystyki energetycznej (Dz.U. 2015 poz. 376).

Rozporządzenie Ministra Infrastruktury z dnia 12 kwietnia 2002 r. w sprawie warunków technicznych, jakim powinny odpowiadać budynki oraz ich usytuowanie (Dz.U. $2002 \mathrm{nr} 75$ poz. 690).

Solarek, K. (2014). Struktura przestrzenna strefy podmiejskiej Warszawy. Determinanty wspótczesnych przekształceń. Warszawa: Oficyna Wydawnicza Politechniki Warszawskiej.

\section{WYKORZYSTANIE ODNAWIALNYCH ŹRÓDEŁ ENERGII JAKO NARZĘDZIA WSPIERAJĄCEGO OCHRONĘ WARTOŚCI KULTUROWYCH PRZEDMIEŚĆ NA PRZYKŁADZIE DWORU W WARSZAWIE-BIAŁOŁĘCE}

\section{STRESZCZENIE}

Celem artykułu jest zaprezentowanie wyników badań na temat możliwości wykorzystania alternatywnych źródeł energii i rozwiązań proekologicznych jako narzędzia wspierającego ochronę kulturowego i naturalnego krajobrazu przedmieść Warszawy. W sąsiedztwie Warszawy znajdują się pojedyncze budynki lub zespoły, które stanowią o tożsamości tego obszaru. Trudność polega na dostosowaniu ich do obowiązujących standardów energetycznych bez ingerencji w ich bryłę i materiał, zwłaszcza w odniesieniu do budynków drewnianych. Zamiast poddawać je termomodernizacji, co jest wykluczone w przypadku drewnianych obiektów, warto rozważyć zastosowanie fotowoltaiki. Do analiz szczegółowych został wybrany dwór w Warszawie-Białołęce. Badanie wykazało zasadność zastosowania w tym przypadku 26 paneli fotowoltaicznych o mocy $7,54 \mathrm{~kW}_{\mathrm{p}}$. Obliczono przybliżony prosty czas zwrotu kosztów inwestycji na około 10 lat. W celu zniwelowania negatywnego wpływu na estetykę obiektu zalecono zastosowanie odpowiedniego koloru paneli lub dachówek fotowoltaicznych, choć wówczas należy liczyć się ze wzrostem kosztów inwestycji. Wyniki pokazały niezaprzeczalne korzyści, w tym ekonomiczne, wynikające z zastosowania zaproponowanych rozwiązań.

Słowa kluczowe: ochrona zabytków, energia odnawialna, instalacje fotowoltaiczne, dwór w Białołęce, przedmieścia Warszawy 
